\title{
Lactococcal 936-Species Phage Attachment to Surface of Lactococcus lactis
}

\author{
B. L. Geller, ${ }^{1}$ H. T. Ngo, ${ }^{2}$ D. T. Mooney, ${ }^{1}$ P. Su, ${ }^{3}$ and N. Dunn ${ }^{2}$ \\ ${ }^{1}$ Department of Microbiology, Oregon State University, Corvallis, 97331 \\ 2Department of Biotechnology, University of New South Wales, Sydney, Australia \\ ${ }^{3}$ DSM Food Specialties, Moorebank, New South Wales, Australia
}

\section{ABSTRACT}

The interactions of the 936-species phages sk1, jj50, and 64 with the cell surface of Lactococcus lactis LM0230 were analyzed. Cell envelopes (walls + plasma membrane), cell wall, or plasma membrane from $L$. lactis ssp. lactis LM0230 each inactivated the phages in vitro. However, other 936-species phages kh and P008, which do not infect strain LM0230, were not inactivated by any of the subcellular fractions. Treating cell walls or plasma membrane with the cell wall hydrolase mutanolysin eliminated inactivation of phage sk 1 . This suggested that intact cell wall fragments were required for inactivation. A role for plasma membrane in phage sk1 inactivation was further investigated. Boiling, washing in $2 M \mathrm{KCl}, 8 M$ urea, or $0.1 M \mathrm{Na}_{2} \mathrm{CO}_{3} / \mathrm{pH} 11$, or treating the plasma membrane with proteases did not reduce adsorption or inactivation of phage. Adding lipoteichoic acid or antibodies to lipoteichoic acid did not reduce inactivation of phage in a mixture with membrane, suggesting that lipoteichoic acid was not involved. Inactivation by envelopes or cell wall correlated with ejection of DNA from the phage sk1 capsid. Although calcium is required for plaque formation, it was not required for adsorption, inactivation, or ejection of phage DNA by envelopes or cell wall. The results suggest that at least for phages sk1,jj50, and 64, adsorption and phage DNA injection into the host does not require a host membrane protein or lipoteichoic acid, and that cell wall components are sufficient for these initial steps of phage infection.

(Key words: Lactococcus lactis, phage, phage attachment)

\begin{abstract}
Abbreviation key: BisTris = bis[hydroxyethyl]iminotris [hydroxymethyl]methane, EGTA = ethyleneglycolbis- ( $\beta$-aminoethyl ether) $\mathrm{N}, \mathrm{N}, \mathrm{N}^{\prime}, \mathrm{N}^{\prime}$-tetraacetic acid, $\alpha$ GP $=$ DL- $\alpha$-glycerophosphate.
\end{abstract}

Received February 20, 2004.

Accepted October 28, 2004.

Corresponding author: Bruce L. Geller; e-mail: gellerb@orst.edu.

\section{INTRODUCTION}

Lactococcus lactis is a commercially important bacterium used to make fermented dairy products such as cheese and sour cream. Phage infection of L. lactis during fermentation of milk is a troublesome and persistent economic problem in factories where fermented dairy products are produced. Lactococcal phages are normal contaminants of milk that multiply during fermentation of the milk. Sanitation of factory equipment and rotation of strains used to ferment the milk reduce, but do not eliminate, the problem. Genetic modification of starter culture strains of $L$. lactis has significantly reduced the sensitivity toward phages commonly found in cheese factories (Coffey and Ross, 2002).

One strategy that improves phage resistance of $L$. lactis is to genetically delete expression of the Pip protein (Garbutt et al., 1997; Kraus and Geller, 1998). Pip is a host-encoded receptor for $\mathrm{c} 2$ species phage, which is 1 of the 3 lactococcal phage species (Jarvis et al., 1991; Brussow, 2001) that predominate in cheese factories. Pip apparently is not a receptor for the other 2 lactococcal phage species (936 and P335). If a similar strategy of improving resistance to 936 and P335 phages were possible, then identifying the mechanism by which these phage attach to the bacterial cell surface would help in designing genetic tactics for removing or modifying cell surface phage receptors.

Phage receptors on gram-positive bacteria are usually associated with nonproteinaceous components of the cell wall (Beumer et al., 1984; Valyasevi et al., 1990; Estrela et al., 1991; Schafer et al., 1991; Valyasevi et al., 1994; Quiberoni et al., 2000). Pip is an exception to the norm for gram-positive phage receptors. Other than S-layer or flagellar proteins, it is the only known plasma membrane-associated protein that acts as a phage receptor on gram-positive bacteria (Archibald, 1980). But even c2-species lactococcal phage apparently adsorb to carbohydrate receptors before or concurrently with Pip (Monteville et al., 1994). It appears that multiple receptors for a single phage are common among gram-positive bacteria (Archibald, 1980). The cell wall receptors for two 936-species lactococcal phages, sk1 and kh, have 
been partially characterized (Valyasevi et al., 1990, 1994). Both include rhamnose and other sugars commonly found in the cell wall of $L$. lactis. Recently, genes involved in the synthesis of cell wall carbohydrate have been identified and found to be required for adsorption of 936-species phages bIL170 and $\Phi 645$ (Dupont et al., 2004a).

This report presents biochemical data that attachment to the lactococcal surface of a 936 species phage (sk1) is to the cell wall only and not to a membrane protein. The report confirms that calcium (Collins et al., 1950; Sozzi, 1972) is not required for adsorption and inactivation of phage sk 1 by cell walls.

\section{MATERIALS AND METHODS}

\section{Bacterial Strains, Phages, Growth Conditions}

Lactococcus lactis ssp. lactis LM0230 (host for phages sk1, jj50, 64, and c2), C2 (pip ${ }^{-}$), and HER1228 (host for phage P008), and L. lactis ssp. cremoris $\mathrm{KH}$ (host for phage $\mathrm{kh}$ ) were grown at $30^{\circ} \mathrm{C}$ on M17 medium (Terzaghi and Sandine, 1975) plus 0.5\% glucose (M17G). Escherichia coli HB101 was grown in Luria Bertoni medium (Miller, 1977). Lysates of phage were prepared from single plaques as described (Terzaghi and Sandine, 1975). Phage titer was determined as described (Valyasevi et al., 1990).

\section{Isolation and Purification of Plasma Membrane, Cell Wall, and Cell Envelope}

Plasma membrane and cell wall from $L$. lactis LM0230 were isolated as described (Valyasevi et al., 1991), including hot SDS treatment of envelopes to remove plasma membrane. Plasma membrane from $E$. coli HB101 was isolated by the lysozyme-EDTA method of Kaback (Kaback, 1971; Short et al., 1975), and further purified on the optional 2-step sucrose gradient. Envelopes were prepared as described (Valyasevi et al., 1990), except that cells were resuspended to 67 rather than $150 \mathrm{mg} / \mathrm{mL}$, glass beads were removed by centrifugation instead of filtration, and the SDS treatment was replaced with 2 centrifugations at $1400 \times g, 5 \mathrm{~min}, 4^{\circ} \mathrm{C}$, from L. lactis C2 (pip $\left.{ }^{-}\right)$. Lactococcus lactis $\mathrm{C} 2$ (pip ${ }^{-}$) has a site-specific ochre mutation in pip and was constructed as described (Kraus and Geller, 2001) using strain $\mathrm{C} 2$, which is the wild-type strain from which LM0230 is derived. Plasma membrane, cell wall, and envelope preparations were quantified by measuring total phosphate (Ames, 1966), protein (Bradford, 1976; BSA as standard), and sugar (DuBois et al., 1956; glucose as standard). Plasma membrane had protein:phosphate $=36$ to $71 \mathrm{mg} / \mathrm{mmol}$ and protein:sugar $=0.2$ to
$0.6 \mathrm{mg} / \mathrm{mg}$. Cell walls had a protein:sugar $=0.1 \mathrm{mg} / \mathrm{mg}$. Envelopes had a protein:sugar $=0.1$ to $0.3 \mathrm{mg} / \mathrm{mg}$.

\section{Phage Inactivation}

In a final volume of $25 \mu \mathrm{L}$ of $100 \mathrm{~m} M$ (bis[hydroxyethyl]iminotris[hydroxymethyl]methane) (BisTris)/1 $\mathrm{mM} \mathrm{CaCl} 2$ (pH 6.8), approximately $2.5 \times 10^{2}$ plaqueforming units (pfu) were mixed on ice with or without plasma membrane, cell wall, envelope, or whole cells. The final concentration of membrane, cell wall, or envelope was equivalent to $100 \mathrm{~m} M$ phosphate, $70 \mathrm{~m} M$ glucose, or $15 \mathrm{~m} M$ glucose, respectively, unless otherwise indicated. Whole cells from $0.5 \mathrm{~mL}$ of an overnight culture were washed 3 times in $0.5 \mathrm{~mL}$ of $100 \mathrm{~m} M$ BisTris, $\mathrm{pH} 6.8$ and resuspended in same buffer to $0.5 \mathrm{~mL}$. Washed cells $(0.5 \mu \mathrm{L})$ were mixed with phage and incubated 2 to $4 \mathrm{~h}$ on ice. The phage titer was determined using duplicate $10-\mu \mathrm{L}$ aliquots. Inactivation of phage was calculated by dividing the average phage titer of the sample with membrane or cell wall by the average phage titer of a similar mixture without membrane or cell wall, subtracting the quotient from 1 , and multiplying by 100 .

\section{Phage Adsorption}

Phage were mixed with membrane, cell wall, envelope, or washed whole cells and incubated as described above for inactivation. Following incubation, the mixture was centrifuged at $17,000 \times g, 5 \mathrm{~min}, 4^{\circ} \mathrm{C}$, and the supernatant was removed. The phage titer of the supernatant was determined in duplicate. The percentage of bound phage was calculated by dividing the titer of the supernatant by the titer of the mixture before centrifugation, subtracting from 1 , and multiplying by 100 .

\section{Treatment of Membrane, Cell Wall, and Envelope}

Purified plasma membrane was diluted to $0.5 \mathrm{mM}$ phosphate equivalent in $100 \mu \mathrm{L}$ of $2 M \mathrm{KCl} / 100 \mathrm{~m} M$ BisTris pH 6.8, $8 M$ urea/100 $\mathrm{m} M$ BisTris $\mathrm{pH} 6.8$, or $100 \mathrm{mM} \mathrm{Na} \mathrm{CO}_{3} / \mathrm{pH} 11$ and incubated on ice for $3 \mathrm{~h}$. The membranes were collected by centrifugation $(20,000 \times$ g, $10 \mathrm{~min}, 4^{\circ} \mathrm{C}$ ), washed in $100 \mu \mathrm{L}$ of BisTris $\mathrm{pH} 6.8$, suspended to $2.5 \mathrm{~m} M$ phosphate equivalent in $100 \mathrm{~m} M$ BisTris pH 6.8, and tested for inactivation of phage as described above. Recovery of membranes was equivalent for all treatments, as determined by total phosphate analysis.

Purified plasma membrane was diluted to $2.5 \mathrm{mM}$ phosphate equivalent in $21 \mu \mathrm{L}$ of $100 \mathrm{~m} M$ BisTris $\mathrm{pH}$ 6.8. Trypsin, chymotrypsin, pepsin, papain, or protein- 
ase $\mathrm{K}$ was added to final concentrations of $1 \mathrm{mg} / \mathrm{mL}$. Alternatively, membrane was diluted to 1 to $2 \mathrm{~m} M$ phosphate equivalent and mixed with either 25 units of mutanolysin (Boehringer, Germany, or Sigma Chemical Co., St. Louis) or $15 \mathrm{mg} / \mathrm{mL}$ lysozyme (Sigma Chemical Co.). Controls without enzyme but with membrane, or without membrane but with enzyme were included. Mixtures were incubated 1 to $2 \mathrm{~h}$ at $37^{\circ} \mathrm{C}$. Phenylmethylsulfonyl fluoride $(1 \mathrm{mM})$ was added to the mixtures with trypsin, chymotrypsin, and proteinase $\mathrm{K}$ and incubated for $30 \mathrm{~min}$ at $37^{\circ} \mathrm{C}$. The treated membranes were tested for inactivation of phage as described above.

Cell wall was diluted in $50 \mathrm{~m} M$ Tris- $\mathrm{HCl}, \mathrm{pH} 8.0$ to $18 \mathrm{~m} M$ glucose equivalent, mixed with a final concentration of $20 \mathrm{mg} / \mathrm{mL}$ lysozyme or 50 units of mutanolysin, and incubated at $37^{\circ} \mathrm{C}$ for $2 \mathrm{~h}$. Treated cell walls were isolated by centrifugation $(10,000 \times g, 10 \mathrm{~min}$, $4^{\circ} \mathrm{C}$ ), washed twice in one volume, and resuspended in $50 \mathrm{~m} M$ Tris- $\mathrm{HCl}, \mathrm{pH}$ 8.0.

Aliquots $(0.5 \mathrm{~mL}$ ) of isolated envelopes ( $4 \mathrm{~m} M$ glucose equivalent) were boiled with or without $0.1 \%$ SDS for $10 \mathrm{~min}$. A control aliquot $(0.5 \mathrm{~mL})$ without SDS was not boiled. Envelopes were washed 3 times in $1 \mathrm{~mL}$ of either $0.1 \%$ SDS (aliquot treated with SDS), $\mathrm{H}_{2} \mathrm{O}$ (boiled aliquot), or $10 \mathrm{~m} M$ BisTris, pH 6.8 (not boiled), and isolated by centrifugation at $17,900 \times \mathrm{g}, 10 \mathrm{~min}, 20^{\circ} \mathrm{C}$. Following this, envelopes were washed 3 times in 30 $\mathrm{mL}$ of $\mathrm{H}_{2} \mathrm{O}$, and collected by centrifugation as described above. Finally, treated and washed envelopes were resuspended in $0.5 \mathrm{~mL}$ of $10 \mathrm{~m} M$ BisTris, $\mathrm{pH}$ 6.8.

\section{Inhibitors of Inactivation}

The following substances were added to the phage inactivation assay at a final concentration of $100 \mathrm{mM}$ : DL- $\alpha$-glycerophosphate ( $\alpha$-GP; pH 6.8), glycerol, $\mathrm{K}_{2} \mathrm{HPO}_{4}\left(\mathrm{pH}\right.$ 6.8), $\mathrm{Na}_{2} \mathrm{HPO}_{4}$ (pH 6.8), D-glucose, D-galactose, D-alanine, rhamnose, o-phosphorylethanolamine, $\mathrm{N}$-acetylglucosamine, and ethyleneglycol-bis-( $\beta$-aminoethyl ether) $\mathrm{N}, \mathrm{N}, \mathrm{N}^{\prime}, \mathrm{N}^{\prime}$ - tetraacetic acid (EGTA, $\mathrm{pH}$ 7.0). Controls without membrane or cell wall, but with inhibitor, were used to calculate the percentage inhibition.

Lipoteichoic acid (Biotrend, Chemikalien $\mathrm{GmbH}$, Cologne, Germany) or antiteichoic acid monoclonal antibody (clone 55, HyCult Biotechnology BV, Uden, the Netherlands) was added to the phage inactivation assay at a final concentration of 20 or $0.4 \mu \mathrm{g} / \mathrm{mL}$, respectively.

\section{Phage DNA Ejection}

Phage sk1 was labeled with $\left[{ }^{3} \mathrm{H}\right]$ thymidine (Amersham Biosciences, Piscataway, NJ) as described (Monteville et al., 1994) with the following exceptions: washed cells were subcultured by diluting $4 \times 10^{-3}$ into $6 \mathrm{~mL}$ of SLSD medium supplemented with $24 \mu \mathrm{Ci}$ of $\left[{ }^{3} \mathrm{H}\right]$ thymidine. When the culture reached an optical density $(600 \mathrm{~nm})$ of $\sim 0.35, \mathrm{CaCl}_{2}(10 \mathrm{mM}), 18 \mu \mathrm{Ci}$ of $\left[{ }^{3} \mathrm{H}\right]$ thymidine, and phage sk1 (multiplicity of infection $=2$ ) were added.

Membranes ( $1 \mathrm{~m} M$ phosphate equivalent), walls (7.2 $\mathrm{m} M$ glucose equivalent), or envelopes ( $1 \mathrm{~m} M$ glucose equivalent) were mixed with $2 \times 10^{8}$ pfu of $\left[{ }^{3} \mathrm{H}\right]$ phage sk1 $\left(2 \times 10^{-6} \mathrm{cpm} / \mathrm{pfu}\right)$ in $25 \mu \mathrm{L}$ of $100 \mathrm{~m} M$ BisTris-HCl, $5 \mathrm{mM} \mathrm{CaCl}$, pH 6.8 or $100 \mathrm{~m} M$ BisTris-HCl, $10 \mathrm{mM}$ EDTA, pH 6.8. Mixtures were incubated on ice for $2 \mathrm{~h}$. Samples $(2 \mu \mathrm{L})$ of each mixture were diluted in M17 broth and the phage titer was determined. To the remainder of each mixture was added $\mathrm{MgCl}_{2}(20 \mathrm{mM})$ and 10 units $(4 \mu \mathrm{g})$ of bovine pancreas deoxyribonuclease I (Sigma Chemical Co.). The mixture was digested for 1.5 $\mathrm{h}$ at $37^{\circ} \mathrm{C}$. Bovine serum albumin $(40 \mu \mathrm{g} / \mathrm{mL})$, salmon sperm DNA ( $40 \mu \mathrm{g} / \mathrm{mL})$, and trichloroacetic acid (10\%) were added, and the mixture was incubated on ice for $15 \mathrm{~min}$. Half of the volume was removed and transferred to a liquid scintillation vial. The other half was centrifuged at $16,000 \times g, 10 \mathrm{~min}, 4^{\circ} \mathrm{C}$. The supernatant was removed and transferred to a liquid scintillation vial (trichloroacetic acid-soluble). The pellet was resuspended in $40 \mu \mathrm{L}$ of $100 \mathrm{~m} M$ BisTris, $\mathrm{pH} 6.8$ and transferred to a liquid scintillation vial (trichloroacetic acid-insoluble).

\section{RESULTS}

\section{Cell Envelope Inactivates Phage sk1}

Cell envelope, which includes both plasma membrane and cell wall (peptidoglycan), was mixed, and incubated on ice with the 936 -species phage sk 1 , jj50, or 64 . All 3 phages form plaques on LM0230. The phage titer was measured. Phage sk1 was inactivated $100(\mathrm{SD}=0, \mathrm{n}=$ $3)$, phage jj50 was inactivated $70(\mathrm{SD}=5, \mathrm{n}=4)$, and phage 64 was inactivated $95 \%(\mathrm{SD}=3, \mathrm{n}=3)$. Envelopes failed to inactivate other 936-species phage $\mathrm{kh}$ and P008, which do not form plaques on strain LM0230.

\section{Cell Wall Inactivates Phage sk1}

Cell wall from strain LM0230 was prepared from envelope by removing the plasma membrane with detergent. Cell wall was mixed and incubated with phage sk1, jj50, or 64 . Phage sk1, jj50, and 64 were inactivated $99(\mathrm{SD}=1, \mathrm{n}=5), 80(\mathrm{SD}=20, \mathrm{n}=2)$, and $96 \%(\mathrm{SD}=$ $3, \mathrm{n}=2$ ), respectively. Phages $\mathrm{kh}$ and $\mathrm{P} 008$ were inactivated $3(\mathrm{SD}=4, \mathrm{n}=2)$ and $0 \%(\mathrm{SD}=0, \mathrm{n}=2)$, respectively.

Cell wall was treated with a lysozyme or mutanolysin and mixed with phage sk1. Lysozyme-treated cell wall 
Table 1. Phage inactivation by plasma membranes in vitro.

\begin{tabular}{lllll}
\hline \multirow{2}{*}{$\begin{array}{l}\text { Membrane } \\
\text { pretreatment }\end{array}$} & \multicolumn{4}{c}{$\%$ Inactivation $(\mathrm{SD}, \mathrm{n})$} \\
\cline { 2 - 5 } & Phage sk1 & Phage c2 & Phage jj50 & Phage 64 \\
\hline None & $95(5,6)$ & $93(7,8)$ & $72(5,5)$ & $97(3,3)$ \\
$2 M$ KCl & $98(0,2)$ & $\mathrm{ND}^{1}$ & $\mathrm{ND}$ & $\mathrm{ND}$ \\
$8 M$ urea & $98(1,2)$ & $\mathrm{ND}$ & $\mathrm{ND}$ & $\mathrm{ND}$ \\
pH 11 & $96(2,2)$ & $\mathrm{ND}$ & $\mathrm{ND}$ & $\mathrm{ND}$ \\
$100^{\circ} \mathrm{C}, 15$ min & $97(2,3)$ & $12(16,2)$ & $50(7,3)$ & $86(13,2)$ \\
Proteinase K & $90(10,8)$ & $\mathrm{ND}(5,2)$ & $\mathrm{ND}, 3)$ & $92(6,2)$ \\
Trypsin & $98(1,2)$ & $\mathrm{ND}$ & $\mathrm{ND}$ & $\mathrm{ND}$ \\
Chymotrypsin & $98(0,2)$ & $86(18,2)$ & $\mathrm{ND}$ & $\mathrm{ND}$ \\
Mutanolysin & $0(0,2)$ & $86(16,3)$ & $8(3,3)$ & ND \\
Lysozyme & $1(2,7)$ & & & $3(10,3)$ \\
\hline
\end{tabular}

${ }^{1} \mathrm{ND}=$ No data.

inactivated $84 \%(\mathrm{SD}=15, \mathrm{n}=3$ ) of phage $\mathrm{sk} 1$, whereas mutanolysin-treated wall inactivated $0 \%(\mathrm{SD}=0, \mathrm{n}=$ 2 ) of the phage. Extending the lysozyme treatment from 2 to $24 \mathrm{~h}$ had no significant effect on the results.

\section{A Role for Plasma Membrane in Phage sk1 Inactivation?}

Although the above results showed that cell walls without plasma membrane were sufficient to inactivate phage sk1, we hypothesized that plasma membrane may also inactivate phage sk1, which is the case for phage c2. Plasma membrane from L. lactis LM0230 was mixed with either phage sk1 (species 936) or phage c2 (species c2) and incubated on ice. The phage titer of each mixture was measured. Plasma membrane reduced the phage titer by 95 and $93 \%$ for phage sk 1 and c2, respectively (Table 1 , no pretreatment). No inactivation of phage sk 1 was found in mixtures that contained plasma membrane from $E$. coli instead of $L$. lactis. Plasma membrane also inactivated phages jj50 and 64 by 72 and $97 \%$, respectively (Table 1 ).

Although isolation of plasma membranes included lysozyme treatment, fragments of cell wall could adhere to membranes and cause phage inactivation. Purified membranes were digested further with an additional treatment of lysozyme or mutanolysin, then mixed and incubated with phage sk1. Membranes further treated with lysozyme or mutanolysin failed to inactivate phage sk1 (Table 1). As a control, treated membranes were shown to inactivate phage $\mathrm{c} 2$, which depends on the membrane protein Pip (Table 1). Lysozyme or mutanolysin treatment of phage alone did not inactivate the phage. This suggests that peptidoglycan-associated material is required for phage sk1 inactivation, and that membrane may not play a role in phage sk1 inactivation. Similar results were found for other 936-species phages jj50 and 64 (Table 1).

The loss of inactivation of phage after treatment of membrane preparations with mutanolysin correlated with loss of phage sk1 adsorption. Mutanolysin-treated membrane was mixed and incubated with phage sk1. Following incubation, the mixture was centrifuged to remove membrane-bound phage. The titer of the supernatant after centrifugation was $100 \%(\mathrm{SD}=0.7, \mathrm{n}=2)$ of the titer of the mixture before centrifugation. This result showed that cell wall fragments, which apparently copurified with plasma membrane, are required in the membrane preparation for in vitro inactivation of phage sk1.

If plasma membrane plays any role in the in vitro inactivation of phage sk1, then treating the membrane preparation (including the apparent cell wall fragments) with reagents that either destroy or mimic membrane components might reduce the inactivation. We first tested this by washing the membrane preparation in $2 M \mathrm{KCl}, \mathrm{pH} 11$ buffer, or $8 M$ urea, which disrupt noncovalent bonds and dissociate weakly bound material. After treatment, membrane was reisolated by centrifugation and resuspended in $\mathrm{pH} 6.8$ buffer. Treated membrane was mixed and incubated with phage sk1. None of the treatments reduced the inactivation of phage by the membrane preparation (Table 1).

\section{Heat- or Protease-Treated Plasma Membrane}

Isolated plasma membrane was incubated at $100^{\circ} \mathrm{C}$ for 15 min before cooling to $0^{\circ} \mathrm{C}$ and mixing with phage sk1. Boiling did not reduce the effect on phages sk1, jj50, or 64 , but abolished the ability of plasma membrane to inactivate phage $\mathrm{c} 2$, which requires the membrane protein Pip as a receptor (Table 1).

Isolated plasma membrane was mixed and incubated with proteinase K, trypsin, or chymotrypsin. Protease inhibitors were added, and the proteolyzed membrane was mixed and incubated with phage. Protease-treated membrane inactivated phage sk1,jj50, or 64 to the same extent as the untreated controls, but did not inactivate phage c2 (Table 1). Proteases or protease inhibitors 
Table 2. Phage sk1 adsorption to plasma membrane in vitro.

\begin{tabular}{ll}
\hline Inhibitor $(0.1 M)$ & $\begin{array}{l}\% \text { Irreversible } \\
\text { adsorption } \\
(\mathrm{SD}, \mathrm{n})\end{array}$ \\
\hline None & $95(5,6)$ \\
L-Rhamnose & $96(3,3)$ \\
D-Glucose & $91(7,2)$ \\
D-Galactose & $94(3,2)$ \\
N-acetylglucosamine & $99(0,2)$ \\
D-alanine & $98(1,2)$ \\
o-Phosphorylethanolamine & $75(22,3)$ \\
$\alpha$-Glycerophosphate, pH 6.8 & $6(11,6)$ \\
Glycerol & $90(6,2)$ \\
Na $_{2} \mathrm{HPO}_{4}, \mathrm{pH}$ 6.8 & $74(4,3)$ \\
\hline
\end{tabular}

without membranes did not inactivate the phages (data not shown).

\section{Inhibition of Inactivation}

Various chemicals that resemble components of the plasma membrane or peptidoglycan were mixed and incubated with plasma membrane and phage sk1. $\alpha$-Glycerophosphate inhibited inactivation of the phage by the membrane (Table 2). Glycerol, $\mathrm{Na}_{2} \mathrm{HPO}_{4}$, D-alanine, $\mathrm{N}$-acetylglucosamine, rhamnose, glucose, galactose, or o-phosphorylethanolamine had no effect. $\alpha$-Glycerophosphate is part of the structure of lipoteichoic acid, and might act like a competitive inhibitor. These results suggested that lipoteichoic acid might participate in the inactivation of phage sk1.

\section{Lipoteichoic Acid}

Phage sk1 was mixed with purified lipoteichoic acid. An amount of membrane that had previously been shown to inactivate about half the phage was added. In the presence of lipoteichoic acid, $42 \%(\mathrm{SD}=9, \mathrm{n}=$ 2 ) of phage sk1 was inactivated by membranes, and $0 \%$ $(\mathrm{SD}=1, \mathrm{n}=2)$ without membranes. Without lipoteichoic acid, membrane inactivated $47 \%(\mathrm{SD}=1, \mathrm{n}=2)$ of phage sk1.

Antiserum to lipoteichoic acid was included in a mixture of membrane and phage sk1. Phage sk 1 was inactivated $100(\mathrm{SD}=0.7, \mathrm{n}=2)$ and $98 \%(\mathrm{SD}=2.1, \mathrm{n}=2)$ with antiserum against lipoteichoic acid or with nonimmune serum, respectively. These results show that lipoteichoic acid did not inactivate phage sk1 or block inactivation.

\section{$\alpha$-GP and Calcium}

The inhibitory effect of $\alpha$-GP may be linked to its ability to bind or precipitate calcium, which is required for phage sk1 infection. This was tested by adding an

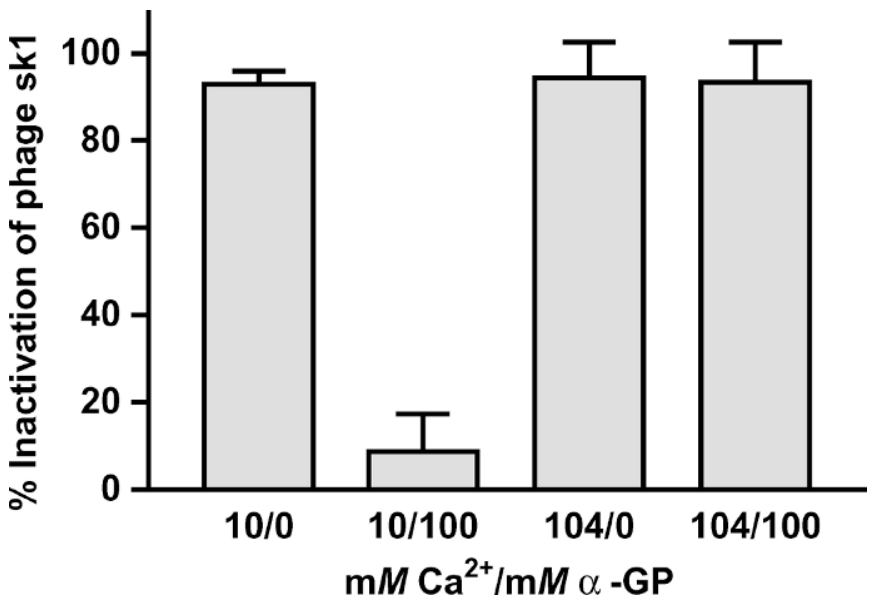

Figure 1. $\mathrm{Ca}^{2+}$ reverses inhibition of inactivation by $\alpha$-glycerophosphate $(\alpha-\mathrm{GP})$. Phage sk1 was mixed with membrane and the indicated amounts of $\mathrm{CaCl}_{2}$ and $\alpha$-GP. After incubation for $4 \mathrm{~h}$ at $0^{\circ} \mathrm{C}$, the phage titer of the mixture was determined. Error bars indicate standard deviation $(\mathrm{n}=2)$.

excess of calcium to a mixture of phage sk1 and membrane. The results showed that excess calcium reversed the effect of $\alpha$-GP (Figure 1).

\section{Calcium-Independent Adsorption to Cell Wall}

Although the requirement for calcium in phage sk1 infection is well established, the role of calcium is not understood. We hypothesized that plasma membrane imparted a calcium-dependency to the cell wall-mediated inactivation of phage sk1. Phage sk1 was mixed with cell wall, envelope, plasma membrane, or lysozyme-treated cell wall, and EGTA was included to chelate residual calcium. Cell wall inactivated $96(\mathrm{SD}=5$, $\mathrm{n}=3)$, envelopes $88(\mathrm{SD}=1.4, \mathrm{n}=2)$, plasma membrane $7(\mathrm{SD}=9, \mathrm{n}=5)$, and lysozyme-treated cell wall $3 \%$ $(\mathrm{SD}=5, \mathrm{n}=3)$ of phage $\mathrm{sk} 1$. The phage titer was not reduced by EGTA alone. This result showed that plasma membrane did not confer to cell envelopes a dependency for calcium in the inactivation of phage sk1.

The adsorption of phage sk1 to cell wall, lysozymetreated cell wall, or whole cells was measured in mixtures without $\mathrm{Ca}^{2+}$. Cell walls bound $95(\mathrm{SD}=7, \mathrm{n}=$ 3 ), lysozyme-treated cells walls $86(\mathrm{SD}=10, \mathrm{n}=2)$, and whole cells $100 \%(\mathrm{SD}=0, \mathrm{n}=2)$ of the phage. This result showed that calcium is not required for adsorption to cell wall in vitro or to intact cells.

The above results showed that lysozyme treatment changed the mechanism of phage inactivation to one that requires calcium. However, the latent requirement for calcium did not correlate with adsorption of phage to cell wall or lysozyme-treated cell wall. 
Table 3. Phage sk1 inactivation (mean $\pm \mathrm{SD} ; \mathrm{n}=2$ ) and ejection (mean $\pm \mathrm{SD} ; \mathrm{n}=2$ ) of DNA.

\begin{tabular}{|c|c|c|c|}
\hline \multirow{2}{*}{$\begin{array}{l}\text { Cellular } \\
\text { components } \\
\text { (mixed with } \\
\text { phage sk1) }\end{array}$} & \multirow[b]{2}{*}{$\%$ Inactivation } & \multicolumn{2}{|c|}{$\%$ DNA ejection } \\
\hline & & $+\mathrm{CaCl}_{2}$ & + EDTA $^{1}$ \\
\hline None & $0^{1}$ & $14 \pm 9.5$ & $18 \pm 3.5^{2}$ \\
\hline Membrane & $88 \pm 4.9$ & $86 \pm 9.1$ & $78 \pm 3.5$ \\
\hline Wall & $100 \pm 0$ & $90 \pm 5.7$ & $94 \pm 2.1$ \\
\hline Envelope & $100 \pm 0$ & $91 \pm 4.2$ & $89 \pm 7.1$ \\
\hline
\end{tabular}

${ }^{1}$ Eighteen percent of the total $\left[{ }^{3} \mathrm{H}\right]$ thymidine-labeled, TCA-precipitable DNA in the phage preparation was accessible to deoxyribonuclease, and was subtracted from the DNA made accessible after incubation with cellular components.

${ }^{2}$ Excess $\mathrm{MgCl}_{2}$ added during deoxyribonuclease digest.

\section{Phage sk1 DNA Ejection}

The nature of inactivation was characterized by measuring the ejection of phage sk1 DNA from the capsid. $\left[{ }^{3} \mathrm{H}\right]$ Thymidine-labeled phage sk1 was mixed with membrane, wall, or envelope. After $2 \mathrm{~h}$, the phage titer was measured and the amount of ejected DNA was analyzed by accessibility to deoxyribonuclease. As expected, each cellular fraction inactivated nearly all the phage (Table 3). Moreover, phage DNA became accessible to nuclease in all mixtures except controls without membrane, wall, or envelope. Similar results were found with or without calcium in the mixture (Table 3).

\section{DISCUSSION}

Many phage apparently adsorb to more than one receptor on the surface of the host. The 2-receptor model of phage adsorption to gram-positive bacteria is thought to confer advantages over a single receptor. Adams and Delbruck proposed (1968) that 2 sequential adsorption steps increase the kinetics and efficiency of phage adsorption. Archibald suggested that the 2-receptor model reduces the chance that phage DNA would be exposed to nucleases in the environment (Archibald, 1980). In the case of $\mathrm{c} 2$ species phages of $L$. lactis, one of the receptors is a cell wall-associated structure composed of carbohydrate (Valyasevi et al., 1991; Monteville et al., 1994). The second receptor is a protein called Pip (Geller et al., 1993). Receptors for other species of lactococcal phages, including 936-species phages such as sk1, include cell wall-associated carbohydrates (Valyasevi et al., 1990, 1994). However, it was unknown if species-936 lactococcal phages use a protein receptor in a manner functionally analogous to Pip. Neither the 936 nor the related P335 species of lactococcal phages use Pip as a receptor (Kraus and Geller, 1998).

In this report, we have shown that host cell wall is necessary and sufficient for adsorption and irreversible inactivation of 936 species phages sk1, jj50, and 64 . However, because both a membrane protein (Pip) and the cell wall participate in adsorption of another species (c2) of lactococcal phages (Monteville et al., 1994), plasma membranes were analyzed further for a role in phage sk1 adsorption and inactivation.

Heat or protease treatment of membrane preparations (which apparently included cell wall fragments) did not decrease the ability of the preparation to inactivate phages $\mathrm{sk} 1$, jj50, or 64 . Other treatments with protein denaturants also had no effect on phage sk1. These results suggest that membrane or cell wall proteins are not required for inactivation, although involvement of an unusually stable protein cannot be eliminated.

$\alpha$-Glycerophosphate significantly reduced inactivation of phage sk1 by membrane preparations (Table 2 ). Neither glycerol nor phosphate had any inhibitory effect on membrane inactivation of phage sk 1 . This suggested that $\alpha$-GP might mimic part of the phage receptor, thereby preventing phage sk 1 from irreversibly adsorbing to the membrane. Lactococcus lactis membrane is composed in part by 2 types of molecules that have $\alpha$-GP as part of their structures: phospholipids and lipoteichoic acid (Wicken and Knox, 1975). Lactococcus lactis apparently lacks wall teichoic acid (Schleifer and Kandler, 1967; Johnson and McDonald, 1974; Valyasevi et al., 1990). Previous work has shown that galactosylcontaining lipoteichoic acid blocks adsorption of a related lactococcal phage, although galactosyl-lipoteichoic acid did not bind phage sk11G (Sijtsma et al., 1990). We hypothesized that lipoteichoic acids might be part of a receptor for species 936 phages. However, neither pure lipoteichoic acid nor antiserum to lipoteichoic acid had any effect on inactivation of phage sk1. This suggests that lipoteichoic acid is not involved in the inactivation of phage sk 1 in vitro, and further supports the conclusion that a membrane component does not participate in adsorption or inactivation of phage sk1. Membranes from $E$. coli failed to inactivate phage sk1, which indicates that phospholipids are not sufficient.

The similar inhibitory effects of $\alpha$-GP and EGTA, a chelator of divalent cations, suggested that $\alpha$-GP inhibited phage inactivation by effectively removing calcium from the mixture. Indeed, phage-inhibitory growth media for commercial strains of $L$. lactis include a variety of phosphate-containing compounds that bind calcium (Sozzi, 1972; Gulstrom et al., 1979; Sandine, 1979). This suggestion was shown to be correct by reversing the effect of $\alpha$-GP with an excess of calcium (Figure 1).

Although calcium is required for plaque formation of phage sk1 in vivo, we were able to show calciumdependency of inactivation in vitro only with cell walls 
or plasma membrane that apparently had been partially hydrolyzed with lysozyme, but not with intact cell walls or envelope. Lysozyme from hen is known not to hydrolyze O-acetylated muramyl subunits (Holtje, 1996), and may leave intact some of the peptidoglycan of L. lactis. Additional treatment (postisolation) of plasma membrane with lysozyme or another muramidase (mutanolysin), which hydrolyzes the same bond as lysozyme but recognizes both $\mathrm{N}$ - and $\mathrm{O}$-acetylated glucosamine (Holtje 1996), eliminated the activity of plasma membrane. This suggests that inactivation of species936 phages such as sk1, jj50, and 64 by membrane preparations was caused by cell wall fragments that copurified with the membranes. The significance of the calcium-dependency for inactivation and the requirement for lysozyme treatment to expose this dependency remains uncertain. Nevertheless, calcium was not required for adsorption to cells, cell walls, or lysozymetreated cell wall. This shows that calcium is required for a step subsequent to adsorption of phage to the cell wall.

The requirement for calcium in phage infections of Lactobacillus or E. coli has been investigated. Calcium is not required for adsorption of phages of Lactobacillus delbrueckii (Quiberoni et al., 2004), Lactobacillus casei (Watanabe and Takesue, 1972), or phage T5 to E. coli (Bonhivers and Letellier, 1995). Its role in phage infection appears linked to maintaining an energized plasma membrane by resealing the membrane after phage DNA injection into the host (Watanabe and Takesue, 1973; Watanabe et al., 1979; Bonhivers and Letellier, 1995). There has also been a suggestion that calcium stabilizes the coiled DNA inside the phage capsid (Sechaud et al., 1988). We showed here that inactivation results from ejection of phage DNA. Furthermore, our results suggest that calcium is not required for ejection. However, because addition of magnesium was required (for deoxyribonuclease) during analysis of the ejected DNA, it is possible that magnesium substituted for calcium and ejection occurred only after magnesium was added.

Theoretically, phage must interact closely with the plasma membrane during infection, to inject the phage genome into the host cell without exposing its DNA to the environment. Indeed, we have confirmed (unpublished results) that deoxyribonuclease has no effect on phage sk1 titer when added to a mixture of phage and indicator strain immediately before infection. However, the ejection of phage DNA upon contact with cell wall in vitro suggests that additional controls must exist in vivo to coordinate intimate association between phage and plasma membrane. We speculate that in vivo, the cell wall receptor positions the phage tail and enables phage tail proteins to form a channel through which phage DNA traverses the plasma membrane. Similar models have been proposed for phage $\lambda$ and T5 infections of E. coli (Roessner and Ihler, 1986; Feucht et al., 1990; Guihard et al., 1992).

The bottom line for applied microbiologists is that engineering of adsorption-defective strains for species 936 phage will probably require manipulation of host genes that control cell wall synthesis, some of which have already been identified (Dupont et al., 2004a). In addition, the recent identification of receptor-binding proteins in 936 species phages may provide new strategies for identifying host receptors and combating phage infections in commercial settings (Dupont et al., 2004b).

\section{CONCLUSION}

In conclusion, as observed for other phages of lactic acid bacteria, this study confirms that cell wall binds and inactivates phage sk 1 and other 936 species of lactococcal phage without the need for calcium. Moreover, plasma membrane was not required for binding and inactivation. Inactivation of phage sk1 by cell wall was caused by ejection of phage DNA.

\section{ACKNOWLEDGMENTS}

This work was supported by a grant from the United States Department of Agriculture through Dairy Management, Inc. and the Western Dairy Center.

\section{REFERENCES}

Adams, G., and M. Delbruck. 1968. Reduction of Dimensionality in Biological Diffusion Processes. Pages 198-215 in Structural Chemistry and Molecular Biology. A. Rich and N. Davidson, ed. W. H. Freeman and Co., San Francisco, CA.

Ames, B. N. 1966. Assay of inorganic phosphate, total phosphate and phosphatases. Meth. Enzymol. 8:115-118.

Archibald, A. R. 1980. Phage receptors in gram-positive bacteria. Pages 7-26 in Receptors and Recognition, Series B, Vol. 7, Virus Receptors Part 1, Bacterial Viruses. L. L. Randall and L. Philipson, ed. Chapman and Hall, London, UK.

Beumer, J., E. Hannecart-Pokorni, and C. Godard. 1984. Bacteriophage receptors. Bull. Inst. Pasteur 82:173-253.

Bonhivers, M., and L. Letellier. 1995. Calcium controls phage T5 infection at the level of Escherichia coli cytoplasmic membrane. FEBS Lett. 374:169-173.

Bradford, M. M. 1976. A rapid and sensitive method for the quantitation of microgram quantities of protein utilizing the principle of protein-dye binding. Anal. Biochem. 72:248-254.

Brussow, H. 2001. Phages of dairy bacteria. Annu. Rev. Microbiol. 55:283-303.

Coffey, A., and R. P. Ross. 2002. Bacteriophage-resistance systems in dairy starter strains: Molecular analysis to application. Antonie Van Leeuwenhoek 82:303-321.

Collins, E. B., F. E. Nelson, and C. E. Parmelee. 1950. The relations of calcium and other constituents of a defined medium to proliferation of lactic streptococcus bacteriophage. J. Bacteriol. 60:533541.

DuBois, M., K. A. Gilles, J. K. Hamilton, P. A. Rebers, and F. Smith. 1956. Colorimetric method for determination of sugars and related substances. Anal. Chem. 28:350-356. 
Dupont, K., T. Janzen, F. K. Vogensen, J. Josephsen, and B. StuerLauridsen. 2004a. Identification of Lactococcus lactis genes required for bacteriophage adsorption. Appl. Environ. Microbiol. 70:5825-5832.

Dupont, K., F. K. Vogensen, H. Neve, J. Bresciani, and J. Josephsen. 2004b. Identification of the receptor-binding protein in 936-species lactococcal bacteriophages. Appl. Environ. Microbiol. 70:5818-5824

Estrela, A. I., H. M. Pooley, H. de Lencastre, and D. Karamata. 1991. Genetic and biochemical characterization of Bacillus subtilis 168 mutants specifically blocked in the synthesis of the teichoic acid poly(3-O-b-D-glucopyranosyl-N- acetylgalactosamine 1-phosphate): gneA, a new locus, is associated with UDP-N-acetylglucosamine 4-epimerase activity. J. Gen. Microbiol. 137:943-950.

Feucht, A., A. Schmid, R. Benz, H. Schwarz, and K. J. Heller. 1990. Pore formation associated with the tail0tip protein pb2 of bacteriophage T5. J. Biol. Chem. 265:18561-18567.

Garbutt, K., J. Kraus, and B. L. Geller. 1997. Bacteriophage resistance in Lactococcus lactis engineered by replacement of a gene for a bacteriophage receptor. J. Dairy Sci. 80:1512-1519.

Geller, B. L., R. G. Ivey, J. E. Trempy, and B. Hettinger- Smith. 1993. Cloning of a chromosomal gene required for phage infection of Lactococcus lactis subsp. lactis C2. J. Bacteriol. 175:5510-5519.

Guihard, G., P. Boulanger, and L. Letellier. 1992. Involvement of phage T5 tail proteins and contact sites between the outer and inner membrane of Escherichia coli in phage T5 DNA injection. J. Biol. Chem. 267:3173-3178.

Gulstrom, T. J., L. E. Pearce, W. E. Sandine, and P. R. Elliker. 1979. Evaluation of commercial phage inhibitory media. J. Dairy Sci. 62:208-221.

Holtje, J.-V. 1996. Bacterial lysozymes. Pages 65-74 in Lysozymes: Model Enzymes in Biochemistry and Biology. P. Jolles, ed. Birkhauser Verlag, Basel, Switzerland.

Jarvis, A. W., G. F. Fitzgerald, M. Mata, A. Mercenier, H. Neve, I. B. Powell, C. Ronda, M. Saxelin, and M. Teuber. 1991. Species and type phages of lactococcal bacteriophages. Intervirology 32:2-9.

Johnson, K. H., and I. J. McDonald. 1974. Peptidoglycan structure in cell walls of parental and filamentous Streptococcus cremoris HP. Can. J. Microbiol. 20:905-913.

Kaback, H. R. 1971. Bacterial membranes. Methods Enzymol. 22:99-120.

Kraus, J., and B. L. Geller. 1998. Membrane receptor for prolate phages is not required for infection of Lactococcus lactis by small or large isometric phages. J. Dairy Sci. 81:2329-2335.

Kraus, J., and B. L. Geller. 2001. Cloning of genomic DNA of Lactococcus lactis that restores phage sensitivity to an unusual bacteriophage sk1-resistant mutant. Appl. Environ. Microbiol. 67:791798.

Miller, J. H. 1977. In Experiments in Molecular Genetics. Cold Spring Harbor Press, New York, NY.

Monteville, M. R., B. Ardestani, and B. L. Geller. 1994. Lactococcal bacteriophages required a host cell wall carbohydrate and a plasma membrane protein for adsorption and ejection of DNA. Appl. Environ. Microbiol. 60:3204-3211.

Quiberoni, A., D. Guglielmottti, A. Binetti, and J. Reinheimer. 2004. Characterization of three Lactobacillus delbrueckii subsp. Bulg- aricus phages and the physicochemical analysis of phage adsorption. J. Appl. Microbiol. 96:340-351.

Quiberoni, A., J. I. Stiefel, and J. A. Reinheimer. 2000. Characterization of phage receptors in Streptococcus thermophilus using purified cell walls obtained by a simple protocol. J. Appl. Microbiol. 89:1059-1065.

Roessner, C. A., and G. M. Ihler. 1986. Formation of transmembrane channels in liposomes during injection of $\lambda$ DNA. J. Biol. Chem. 261:386-390.

Sandine, W. E. 1979. Lactis starter culture technology: history of lactic starters. Pages 15-19 in Pfizer Cheese Monographs, vol. 6. Pfizer, Inc., New York, NY.

Schafer, A., A. Geis, H. Neve, and M. Teuber. 1991. Bacteriophage receptors of Lactococcus lactis subsp. "diacetylactis" F7/2 and Lactococcus lactis subsp. cremoris Wg2-1. FEMS Microbiol. Lett. 77:69-74.

Schleifer, K. H., and O. Kandler. 1967. Zur chemischen zusammensetzung der zellwand der streptococcen. II. Die aminosauresequenz des mureins von Str. lactis und cremoris. Arch. Mikrobiol. 57:365-381.

Sechaud, L., P.-J. Cluzel, M. Rousseau, A. Baumgartner, and J.-P. Accolas. 1988. Bacteriophages of lactobacilli. Biochemie 70:401-410.

Short, S. A., H. R. Kaback, and L. D. Kohn. 1975. Localization of Dlactate dehydrogenase in native and reconstituted Escherichia coli membrane vesicles. J. Biol. Chem. 250:4291-4296.

Sijtsma, L., J. T. M. Wouters, and K. J. Hellingwerf. 1990. Isolation and characterization of lipoteichoic acid, a cell envelope component involved in preventing phage adsorption, from Lactococcus lactis subsp. cremoris SK110. J. Bacteriol. 172:7126-7130.

Sozzi, P. T. 1972. Calcium requirements of lactic starter phages. Milchwissenschaft 27:503-506.

Terzaghi, B. E., and W. E. Sandine. 1975. Improved medium for lactic streptococci and their bacteriophages. Appl. Microbiol. 29:807813

Valyasevi, R., W. E. Sandine, and B. L. Geller. 1990. Bacteriophage $\mathrm{KH}$ receptor of Lactococcus lactis subsp. cremoris $\mathrm{KH}$ is the rhamnose of the extracellular wall polysaccharide. Appl. Environ. Microbiol. 56:1882-1892.

Valyasevi, R., W. E. Sandine, and B. L. Geller. 1991. A membrane protein is required for bacteriophage c2 infection of Lactococcus lactis subsp. lactis C2. J. Bacteriol. 173:6095-6100.

Valyasevi, R., W. E. Sandine, and B. L. Geller. 1994. Lactococcus lactis subsp. lactis $\mathrm{C} 2$ bacteriophage sk1 receptor involving rhamnose and glucose moieties in the cell wall. J. Dairy Sci. 77:1-6.

Watanabe, K., and S. Takesue. 1972. The requirement for calcium in infection with Lactobacillus phage. J. Gen. Virol. 17:19-30.

Watanabe, K., and S. Takesue. 1973. Energy requirement for the formation of blender-resistant complexes in Lactobacillus phage infection. J. Gen. Virol. 20:319-326.

Watanabe, K., S. Takesue, and K. Ishibashi. 1979. Adenosine triphosphate content in Lactobacillus casei and the blender-resistant phage-cell complex-forming ability of cells on infection with PL1 phage. J. Gen. Virol. 42:27-36.

Wicken, A. J., and K. W. Knox. 1975. Characterization of group N Streptococcus lipoteichoic acid. Infect. Immun. 11:973-981. 